\title{
Franchise: A Literature Review and Directions of Future Research
}

\author{
Jinye Li, Hongsheng Xia \\ School of Management, Jinan University, Guangzhou, China \\ Email: lijinye_chenjiayun@163.com
}

How to cite this paper: Li, J.Y. and Xia, H.S. (2019) Franchise: A Literature Review and Directions of Future Research. Open Journal of Business and Management, 7, 817-827.

https://doi.org/10.4236/ojbm.2019.72055

Received: March 7, 2019

Accepted: April 12, 2019

Published: April 15, 2019

Copyright $\odot 2019$ by author(s) and Scientific Research Publishing Inc. This work is licensed under the Creative Commons Attribution International License (CC BY 4.0).

http://creativecommons.org/licenses/by/4.0/

\section{cc) (i) Open Access}

\begin{abstract}
This passage focuses on three hot issues of franchise including the cause of franchise, the legal issues of franchise and the cost structure of franchise. I make a literature review and point out a future research direction of franchise by analyzing and summarizing domestic and foreign papers. In conclusion, for the emergence of the franchise phenomenon, there is still a lack of a unified theoretical framework for a comprehensive and reasonable explanation. The research on the legal issues of franchise is mainly studied by scholars with legal background, mainly focusing on information disclosure system and anti-monopoly law. Besides, there is no theoretical basis and operation method that can be used to guide the franchisor to design the cost structure.
\end{abstract}

\section{Keywords}

Franchise, Information Disclosure, Cost Structure

\section{Introduction}

In 1851, the American Singer Sewing Machine Company sold their sewing machine distribution franchise through a franchise contract, and since then the franchise has been on the stage of history. The franchise is called "the most important business model of the $21^{\text {st }}$ century". A franchisor with certain successful experience can quickly expand at a low cost. On the other hand, franchisees with certain funds can invest in entrepreneurship in a high-success manner. The development speed of franchise is rapid and this business model gradually covers many industries and services. According to the definition of franchise by the International Franchise Association, Franchise is a way of selling products or services, which refers to a contractual relationship between the franchisor and the franchisee. According to the contract, the franchisor provides the franchisee with its unique trademark, trade name or business model, and gives guidance 
and assistance to personnel training, organizational structure, management, and commodity procurement. The franchisee pays the franchisor related costs [1]. In addition, the European Franchise Federation, the World Intellectual Property Organization, and the Ministry of Commerce of China have defined franchise. The definitions of franchise are different, but the basic characteristics are consistent. It is a business model that the franchisor signs a contract with the franchisee, provides trademarks, technology and other business methods, and charges a certain fixed-cost.

Early research focused on the analysis of the reasons for franchise. There are several theoretical explanations in the world, including capital raising, risk sharing, information searching, moral hazard, and principal-agent theory. The second section of this article will elaborate on these theories. Later research mainly focused on the formulation of legal measures for franchising and the existing legal problems, the analysis of the structure of franchise fees, and the franchise model specific to various industries. In general, franchise research has gradually focused on the macro level such as the theoretical exploration to the micro level sucn as specific practical measures. This paper will review the research process and status of the field, and explore the future research direction along the development of the field.

\section{Analysis of the Reasons for Franchising}

There are several theoretical explanations for the reasons why companies choose to adopt a franchise model: Capital raising theory for resource constraints research, information search theory considering decision-making, risk sharing theory from risk sharing, moral risk theory for exploring moral hazard, and principal-agent theory considering agent costs.

\subsection{Capital Rasing Theory}

Capital raising theory is a very popular explanation for franchising in the early days. It believes that raising funds is the reason for enterprises to implement franchise. Franchising is the channel for franchisees to raise funds [1]. This theory is the earliest explanation for the franchise. For the newly established enterprises, funds can be raised through franchising to achieve the purpose of rapid expansion of the enterprises. When the enterprise matures, the company will adopt a completely direct approach to manage their enterprises rather than franchising. Thompson pointed out in his life cycle model that at the beginning of the company, because the company's reputation was not fully established, there was not enough credit to obtain sufficient funds to operate and expand the scale of the company, the franchise approach is the only way to get the money it needs to operate [2].

However, the shortcoming of the capital raising theory is that if the theory is correct, it means that the franchisor will have a higher proportion of directoperated stores after their company matures, but there is no evidence to show 
that this trend has occurred. Martin pointed out that: Franchise stores do not tend to be directly operated by the company over time [3].

\subsection{Information Search Theory}

Minkler proposed that franchising is a way for franchisors to collect and use local information. Because franchisors do not understand the local situation, local franchisees will be more reasonable in making decisions [4]. Perryman and Combs also confirmed this view, and believe that when entering the target market, the company will first franchise a chain store in the region, and if it fails, it will open a direct sales store in the region [5]. The farther away from the company headquarters, the higher the cost of collecting and using information, A study by Brickley and Dark [6] and Norton [7] shows that most of the franchisee's chain stores are downgraded to small markets far from headquarters. Minkler's research also shows that potential franchisees with long operating hours are more likely to obtain franchise rights than potential franchisees with shorter business hours, which further demonstrates that franchisors pay more attention to potential franchisees who understand local information and industry information in order to reduce search costs.

\subsection{Risk Sharing Theory}

Zhang Wuchang first defined risk sharing theory in his doctoral thesis in 1969. He regarded the sharing of contracts as a way to share risks. In other words, the risk of business can be shared between the parties to the contract. He mainly uses the example of landlords and tenant farmers to explain that landlords and tenant farmers are willing to accept the sharing contract under the assumption that the parties to the contract are risk-averse. The choice of contract form can be explained by the difference in transaction costs and the assumption of risk avoidance. As long as the benefit of sharing the risk is higher than the related transaction cost, people choose to sign the share contract instead of choosing to sign the fixed income contract. Because if you sign a fixed income contract, there is no transaction cost. If the revenue of the contracted share is greater than the transaction cost of the contract, according to economic explanation, you will definitely choose the share contract. Martin compares a company's direct sales store to a fixed-income contract, and the franchise store is like a share contract. If the company's headquarters is a higher risk aversion, the company is more inclined to diversify the investment, so the headquarters can use the franchise store to share risks [3].

However, Martin's theory does not provide a sufficient explanation for the situation in reality, and its theoretical assumptions are usually considered to be inconsistent with reality. According to the theoretical logic of risk sharing, the higher the operational risk, the higher the royalties, and the two are positively correlated. However, Lafontaine pointed out that if the operating risk is measured by the proportion of closed stores, from the empirical results, the opera- 
tional risk is negatively related to the royalties [8], which is inconsistent with the conclusion of risk sharing theory.

\subsection{Moral Hazard Theory}

Due to the existence of asymmetric information, the company's direct store knows whether the local demand is high or low, but the headquarters cannot know the status of the demand. Direct stores reduce their level of effort when demand is high, and blame the low output level on the natural state when demand is low, which constitutes the unilateral moral hazard of the branch. Mathewson and Winter focused on the unilateral moral hazard of the store. They believe that if the contract is complete, the store only needs to pay a fixed fee to the headquarters to achieve the best result. But because of the incompleteness of the contract, it needs to be profit sharing is implemented between headquarters and branches [9]. Mathewson and Winter proposed that franchising can solve the problem of moral hazard in the branch. Because the behavior of the branch is difficult to observe, there is moral hazard in the branch. When there is moral hazard, since the income of the direct store has nothing to do with performance, and the headquarters cannot directly observe the efforts of its personnel, it is necessary to supervise the direct store. However, when the cost of supervision is too high, the franchise approach is more efficient and reduces the cost of supervision. According to Rubin, the stores with low-cost supervision is adopted a direct-operated method, and adopt a franchise method for stores with high supervision costs [10].

Scott argues that there is also a moral hazard in the franchisor, that is, a two-way moral hazard problem [11]. Lal proposes a more formal analytical framework: both the franchisor and the franchisee have their own private information. The ethical risk of the franchisee is as described above. The moral risk of the franchisor is mainly manifested in the inability to provide training and support for advertising for the franchisee in time. Therefore, the royalties are paid in installments in order to prevent moral hazard on the franchisor [12].

\subsection{Principal-Agent Theory}

A study by Perryman and Combs shows that when a company has multiple chain stores, he has to hire a store manager in each store [5]. The company needs to supervise each store manager, which will incur supervision costs and will appear agency problem. Barthelemy shows that under normal circumstances, if a chain store is franchised, the franchisor will ask the franchisee to pay for the purchase cost, pay a certain amount of compensation, and abide by the organization's procedures. Correspondingly, the franchisee will get all the residual profits of the store, so the franchisee is self-motivated. Therefore, if the chain store is franchised, there will be no agency problems [13]. However, if they hire a manager to manage the chain store, due to fixed salary and other reasons, there will often be agency problems and supervision is needed. So the owner 
needs to choose between them. The closer a chain store is to the corporate headquarters, the easier it is to supervise. Carney and Gedajlovic argue that chain stores in the same area facilitate the establishment of regional managers for supervision, thereby reducing agency costs [14].

\section{Research on Legal Issues of Franchising}

Franchising is an emerging business model, an economic activity that involves legal and institutional issues in practice, so many studies on franchising focus on legal issues. For example, the information disclosure system is an important legal issue. Before the franchise, there is a serious information asymmetry between the franchisor and the franchisee. The franchisor may abuse its information in order to maximize its own interests. And use its dominant position to induce the franchisee to blindly invest in their franchise system. Solving information asymmetry and providing sufficient information and reasonable time for the franchisee to make rational investment decisions is the key to preventing franchise fraud and protecting the interests of investors. Legal research is a hot topic in current franchise research, but most of the professional content is studied by scholars with legal background. Therefore, I will not elaborate here, only introduce two major legal system issues.

\subsection{The Role of Information Disclosure System in Franchising}

Foreign research on franchise information disclosure system has been very sound, including the US FTC format and UFOC format. At present, domestic research mainly focuses on foreign experience in information disclosure system to improve China's information disclosure system. Huang Guangxi believes that the theoretical basis of the franchise information disclosure system includes information disclosure is the requirement to achieve contractual justice, and is the bond that maintains the trust relationship between the franchise operators, which is conducive to reducing transaction costs [15]. Liu Ying provides advice on the content and legal responsibilities of information disclosure [16]. Han Xingjuan believes that the improvement of China's franchise information disclosure content mainly includes increasing the content of franchise information disclosure and making realistic disclosure requirements for income commitment [17].

A healthy development of the franchise market should have a good order. To create a good market order, we must ensure the integrity of the information disclosure system. As the core of preventing franchise risks, information disclosure provides necessary information for investors' investment judgment, plays an important role in preventing fraud and protecting the interests of investors, and promotes self-discipline of enterprises and facilitates supervision by government departments. This is the value to sout out and explore the study of information disclosure system. Meanwhile, the increasingly prosperous franchise market and its complexity put forward higher requirements for the improvement of China's information disclosure legal system. It is necessary for China to learn from its 
own shortcomings, learn from international advanced experience, refine existing systems, and introduce new good systems in order to promote the further development of China's franchise market.

\subsection{Regulation of Franchising by Antitrust Law}

Franchising is a business model. Its core content is intellectual property, that is, business methods and brand effects are its core competitiveness. On the one hand, the legal monopoly rights enjoyed by the franchisor should be protected; on the other hand, intellectual property rights are a legitimate monopoly power and have the possibility of abuse, so the franchise may have the effect of restricting competition. The actors who restrict competition can easily obtain profits on the basis of not improving efficiency, suppress the natural competitors, weaken the fight against various effective competitions, and are not conducive to the protection of social public interests and consumer rights. It is an obstacle to the healthy development of the market economy. Therefore, restricting competition is the object of legislation in each country. The franchise business model should be included in the review and regulation of the anti-monopoly law. Although the franchisor restricts the franchisee's management freedom through the franchise contract, it is different from the general restrictive competition behavior. Franchising has the rationality and positive meaning of existence, so it is usually treated as a special kind of intellectual property agreement for each country's laws.

Xiang Jing [18] believes that restrictive competition in franchising mainly includes regional restrictions (market segmentation), price collusion, designated supply issues, and refusal to trade: The regional restriction clause is that the franchisor and the franchisee often stipulate regional exclusive rights in the franchise agreement, that is, the franchisor no longer appoints other franchisees to engage in similar business in the area where the franchisee is located; A simple understanding of price collusion is price control, which may also cause antitrust law issues; The designated supply problem is that the franchisor stipulates that the franchisee can only obtain raw materials from the designated supplier, which is not conducive to market competition; The refusal of the transaction is that the franchisor and the franchisee agree not to sell the franchise to other investors, which may result in improper resource allocation. Huang Xiaohui believes that the anti-monopoly law's regulatory focus on franchising can be summarized as two points: First, it is necessary to establish a statutory principle for judging whether the competition is legal or not. Second, it is necessary to explicitly list excessively restrictive competition prohibited by law [19]. However, some scholars believe that franchising must have certain conditions to restrict competition. Rao Yuehong [20] believes that the premise of the anti-monopoly law applicable to franchising must include the following: 1) Whether the franchisor has market dominance; 2) Whether the franchisor abuses market dominance and judges whether the franchisor has abuses should consider two factors. One is whether the restrictive competition behavior is predictable, and the other 
is whether the "lock-in effect" is obvious. Predictability refers to whether the franchisor has shown restrictive competition behavior during the contract stage. The lock-in effect refers to the franchisee's high cost if he wants to withdraw from the franchise system due to the previous investment, that is, although he is free to enter, he is not free to withdraw.

Through the above analysis, we know that the restrictive competition behavior in franchising needs to be under certain conditions, and the anti-monopoly law can regulate the restrictive competition behavior of franchising. The specific conditions vary according to different market conditions and contractual specific matters of each franchise company. Therefore, the academic have not had a specific conclusion, so this has become the most complicated legal issue of the current study of franchise.

\section{Research on the Cost Structure of Franchising}

Before analyzing the cost structure of a franchise, you need to understand the meaning of the two concepts. The initial fee is a one-time fee charged by the franchisor when the franchise is granted to the franchisee. It reflects the value of intangible assets such as brands, patents, business know-how, business models, and goodwill owned by the franchisor. A franchise period is required and only one initial fee is required [21]. After the special business contract expires, if both parties renew, the franchisee needs to pay an initial fee for the next franchise period. Even if the franchisee breaks the contract, the initial fee will not be refunded. Royalties, also known as equity, management fees, etc, are the fees that the franchisee pays regularly to the franchisor according to certain standards or proportions in the course of business. It embodies the rights and interests of the franchisor in the business activities of the franchisee. The amount of royalties can be a fixed amount, that is, the franchisee is required to pay a certain amount of fees on a regular basis regardless of the business conditions during the period. It may also be paid to the franchisor according to the business conditions of the franchisee, for example, according to a fixed proportion of the franchisee's franchise store operating income, operating profit, etc.

In franchising, the fee structure of the franchise fee and the franchise fee is the result of mutual selection between the franchisor and the franchisee. Foreign studies on the structure of franchise fees have been around for 40 years, and they attempt to analyze their components and find the best cost structure. China's research on the structure of franchise fees is less, mainly focused on the game analysis between franchisors and franchisees who hope to achieve their best interests. Therefore, in this chapter, I will mainly introduce the research results of foreign franchise fee structure, and explore the future research direction based on their results.

\subsection{The Cost Structure of Franchising}

Stern and EI-Ansary consider that the fees specified in the franchise contract 
usually include the initial fee and royalties. For franchisors, the setting of these two fees is particularly important because they account for more than $50 \%$ of their total income [22]. Kaumfnan indicated that the initial fee was paid in one lump sum at the beginning of the contract [23]. Klein's study shows that the transaction fee model considers that the initial fee acts as a collateral in the franchise relationship, and that the initial fee can be used to prevent the franchisee from engaging in opportunistic behavior in the future, that is, encroaching on the franchisor's exclusive system-specific assets (such as brand equity) that resulting quasi-rent behavior. Therefore, the initial fee reduces the trading risk by pricing the risk in advance [24]. Klein used the transaction cost theory to prove the positive correlation between the initial fee and the system-specific assets through empirical research [25]. The theory of property rights states that the initial fee is the remuneration of the franchisor to transfer the system-specific practical knowledge to the franchisee at the beginning of the contract. At the beginning of the contract, the higher the franchisor's intangible assets (brand assets), the more rent generated by his actual knowledge, and the higher the initial fee. Dnes also has a similar view [26]. He believes that the franchisor may compensate for the sunk cost through the initial fee, because when the system-specific practical knowledge is very important to the success of the franchise, high sunk costs will occur. At the same time, he further explained the initial fee: the fixed initial fee and the dedicated investment can attract competitive potential franchisee and thus have a screening function. The higher the initial fee and the specific investment, the more likely it is to find a franchisee with a higher entrepreneurial ability.

\subsection{Relationship between Initial Fee and Royalties}

The debate about the relationship between the two costs is fierce. Agency theory believes that under the uncertainty condition, the royalties are set to provide appropriate incentives for the development of the franchisor and the franchisee, and the franchisor extracts the surplus surplus of the brand value through the initial fee [10]. Factors that can reduce royalties will increase the initial fee. Therefore, the research model of the early principal-agent theory means that the initial fee as the present value of all downstream future residual profits should be negatively related to the royalty rate. However, empirical research does not prove a negative relationship between royalties and initial fees. In contrast, Sen shows that a significant positive correlation exists between the initial fee and the royalties [27]. Lafontaine found that the adjustments to the royalty rate and the initial fee were consistent over time [28]. Although Lafontaine is a researcher with a proxy perspective, he points out that the franchisor uses the initial fee not to draw the rent, but to compensate for the cost of recruitment and training. Those franchisors who provide high levels of initial screening and training may also provide a high level of ongoing support services. Therefore, if the initial fee is used to cover the cost of the initial training, and the royalties are used to ex- 
tract the brand value and compensate the franchisor for the ongoing support services, then the two fees will have a positive relationship. The property rights theory also believes that there is a positive relationship between the initial fee and the royalties. The higher the franchisor's system-specific assets, the more rent generated by his actual knowledge, and the higher the initial fee. At the same time, the more intangible investments needed to maintain the brand value during the contract period, the higher the royalties as residual income rights. Windsperger's empirical study of the Austrian charter industry demonstrates the assertion that the property rights theory pointed out [29]. That is the relationship between initial fee and royalties is positive.

\section{Conclusions}

By analyzing and summarizing the three hot research issues and research status of the franchise, the current research characteristics and future research directions are as follows:

For the emergence of the franchise phenomenon, there is still a lack of a unified theoretical framework for a comprehensive and reasonable explanation. In addition to some of the theories mentioned above, there are transaction cost theory, property rights theory, multi-factor theory, etc. Each theory interpretation has its rationality, but at the same time it has its defects. In the early days, this has always been a concern of foreign economic theory research. So far, there have been few empirical studies on these theories. The future research direction can proceed from this point and combine with China's current franchise status.

The legal issues involved in franchising are very complicated. In addition to the information disclosure law and anti-monopoly law mentioned in this article, it also covers the departmental laws such as intellectual property law, contract law, anti-unfair competition law, company law and contract law. In addition to legislation in each country, the regulation of franchising also includes industry self-regulation norms and international norms established by international organizations. The research on this hot spot is based on specific laws, regulations and regulations. Most of the researchers are from the legal profession, and it is not recommended for management background scholars to conduct research. Of course, the legal regulation of franchising is currently a hot spot in the franchise direction. Most of the papers summarized in this paper are domestic scholars' papers. Although there are many foreign studies in this field, most of the practical applications involving the law are not suitable for China's national conditions, so they can be used as advanced experience for reference.

The fee structure of the franchise is mainly concentrated on the cost component. For the business model franchise, the determination of the franchise fee is particularly important. It is usually the dual manifestation of the franchisor's rights and the franchisee's obligations. When the franchisor signed the contract with the franchisee, they reached an unrealistic franchise fee. When the franchisee was not profitable at all or his profit was only enough to pay a high franchise 
fee, the dispute was occurred. At present, China is in the high-speed development period of franchising. There is still little quantitative research on the structure of franchise fees and its influencing factors. There is no theoretical basis and operation method that can be used to guide the franchisor to design the cost structure. The issue of franchise fees is of great significance not only for the performance of franchise contracts, but also for the success of franchise companies and franchisees, and the healthy development of franchise systems. Therefore, relevant research should be conducted on the structure and influencing factors of China's franchise fees. At present, some scholars use game theory to establish models to study the optimization of expenses. Future research can also discuss how to maximize the interests of both franchisors and franchisees from the perspective of economics.

At present, in China, the rapid expansion of enterprises through franchising is in the ascendant, so the in-depth study of the theory will have important guiding significance for enterprise practice. This also requires us to have a deeper understanding of the franchise phenomenon in light of the actual situation of the Chinese concession enterprise. In the process of theoretical discussion, it is of great significance to use the relevant enterprise data to empirically test the franchise theory.

\section{Conflicts of Interest}

The authors declare no conflicts of interest regarding the publication of this paper.

\section{References}

[1] Li, W.H. (2005) Franchise Theory and Practice. Mechanical Engineering Press, New York.

[2] Thompson, R.S. (1994) The Franchise Life Cycle and the Penrose Effect. Journal of Economics Behavior and Organization, 24, 207-218. https://doi.org/10.1016/0167-2681(94)90027-2

[3] Martin, R.E. (1988) Franchising and Risk Management. The American Economic Review, 78, 954-968.

[4] Minkler, A.P. and Park, T.A. (1994) Asset Specificity and Vertical Integration in Franchising. Review of Industrial Organization, 9, 409-423. https://doi.org/10.1007/BF01029514

[5] Perryman, A.A. and Combs, J.G. (2010) Who Should Own It? An Agency-Based Explanation for Multi-Outlet Ownership and Co-Location in Plural Form Franchising. Strategic Management Journal, 33, 368-386. https://doi.org/10.1002/smj.1947

[6] Brickley, J.A. And Dark, F.H. (1987) The Choice of Organizational Form: The Case of Franchising. Journal of Financial Economics, 18, 401-420. https://doi.org/10.1016/0304-405X(87)90046-8

[7] Norton, S.W. (1988) Franchising, Brand Name Capital, and the Entrepreneurial Capacity Problem. Strategic Management Journal, 9, 105-114. https://doi.org/10.1002/smj.4250090711 
[8] Lafontaine, F. (1992) Agency Theory and Franchising: Some Empirical Results. RAND Journal of Economics, 23, 263-283.

[9] Mathewsom, F. and Winter, R.A. (1985) The Economics of Franchise Contracts. Journal of Law and Economics, 18, 503-526. https://doi.org/10.1086/467099

[10] Rubin, P. (1978) The Theory of the Firm and the Structure of the Franchise Contract. Journal of Law and Economics, 21, 223-233. https://doi.org/10.1086/466918

[11] Scott, F.A. (1995) Franchising vs. Company Ownership as a Decision Variable of the Firm. Review of Industrial Organization, 10, 69-81. https://doi.org/10.1007/BF01024260

[12] Lal, R. (1990) Improving Channel Coordination through Franchising. Marketing Science, 9, 299-318. https://doi.org/10.1287/mksc.9.4.299

[13] Barthebremy, J. (2008) Opportunism, Knowledge, and the Performance of Franchise Chains. Strategic Management Journal, 29, 1451-1463. https://doi.org/10.1002/smj.719

[14] Carney, M. and Gedajlovic, E. (1991) Vertical Integration in Franchise Systems: Agency Theory and Resource Explanations. Strategic Management Journal, 12, 607-629. https://doi.org/10.1002/smj.4250120804

[15] Huang, G.X. (2012) On How to Improve China's Franchise Information Disclosure System. Theory Research, 5, 68-69.

[16] Liu, Y. (2012) Research on the Franchise Information Disclosure System. Times Finance, 6, 36-38.

[17] Han, X. (2006) Two Discussions on the Franchise Information Disclosure System. East China University of Political Science and Law, Shanghai.

[18] Xiang, J. (2011) Antitrust Issues in Franchising. Journal of Southwest University, 37, 89-94.

[19] Huang, X.H. (2005) Research on Legal Regulation of Franchising. China University of Political Science and Law, Beijing.

[20] Rao, Y.H. (2009) Several Issues Concerning the Application of Anti-Monopoly Law in Franchising Competition. Law Science Magazine, 1, 124-126.

[21] Liu, M.X. (2005) Research on the Structure of Chinese Franchise Expenses and Its Influencing Factors. Tsinghua University, Beijing.

[22] Stern, L.W., El-Ansary, A., Anderson, E. and Coughlan, A. (1996) Marketing Channels. Prentice Hall, Upper Saddle River, NJ.

[23] Kaumfnan, P.J. and Lafontaine, F. (1992) Costs of Control: The Source of Economic Rents for McDonald's Franchisees. Journal of Law and Economics, 37, 417-453.

[24] Klein, B. and Saft, L.F. (1985) The Law and Economics of Franchise Tying Contracts. Journal of Law and Economics, 28, 345-461. https://doi.org/10.1086/467089

[25] Klein, B. (1995) The Economics of Franchise Contracts. Journal of Corporate Finance, 2, 9-37. https://doi.org/10.1016/0929-1199(95)00003-Q

[26] Dnes, A.W. (1998) A Case Study Analysis of Franchise Contracts. Journal of Legal Studies, 106, 446-452.

[27] Sen, K.C. (1993) The Use of Initial Fees and Royalties in Business-Format Franchising. Managerial and Decision Economics, 14, 175-190. https://doi.org/10.1002/mde.4090140209

[28] Lafontaine, F. and Sugato, B. (1995) The Role of Risk in Franchising. Journal of Corporate Finance, 2, 39-74. https://doi.org/10.1016/0929-1199(95)00004-R

[29] Windsperger, J. (2001) The Fee Structure in Franchising: A Property Rights View. Economics Letters, 73, 219-226. https://doi.org/10.1016/S0165-1765(01)00491-8 